\title{
3-Arylisothiazoloquinols as potent ligands for the benzodiazepine site of $\mathrm{GABA}_{\mathrm{A}}$ receptors
}

\author{
Jakob Nilsson ${ }^{1}$, Elsebet Østergaard Nielsen ${ }^{2}$, Tommy Liljefors ${ }^{3}$, Mogens Nielsen ${ }^{3}$, Olov Sterner ${ }^{1}$ \\ ${ }^{1}$ Division of Organic Chemistry, Lund University, Lund, Sweden \\ ${ }^{2}$ NeuroSearch A/S, Ballerup, Denmark \\ ${ }^{3}$ Faculty of Pharmaceutical Sciences, University of Copenhagen, Copenhagen, Denmark \\ Email: Olov.Sterner@organic.lu.se
}

Received 14 September 2011; revised 20 October 2011; accepted 7 December 2011

\begin{abstract}
3-Arylisothiazolo[5,4-b]quinolin-4(9H)-ones and 3-arylisoxazolo[5,4-b]quinolin-4(9H)-ones were synthesized and assayed for affinity for the benzodiazepine binding site of the $\mathrm{GABA}_{\mathrm{A}}$ receptors. While the 3-arylisothiazoloquinolin-4-ones were found to be potent ligands, with affinities (expressed as the affinity $K_{\mathrm{i}}$ value) down to $1 \mathrm{nM}$, the 3-arylisoxazoloquinolin-4ones are less potent. This is suggested to depend on sterical repulsive interaction of the 3-arylisoxazoloquinolin-4-ones with the receptor essential volume of the binding site, and a higher electron density at the nitrogen in the azole ring $(\mathrm{N}-2)$ as well as the carbonyl oxygen in the isothiazoloquinolin-4-ones enabling them to interact stronger with hydrogen bond donor sites at the binding site.
\end{abstract}

Keywords: Isothiazolo[5,4-b]quinolin-4(9H)-ones; Isoxazolo[5,4-b]quinolin-4(9H)-ones; Benzodiazepine Binding Site; $\mathrm{GABA}_{\mathrm{A}}$ Receptors; $\mathrm{GABA}_{\mathrm{A}}$ Receptor Subtypes; Pharmacophore Model

\section{INTRODUCTION}

$\gamma$-Aminobutyric acid, or GABA, is the major inhibitory neurotransmitter in the central nervous system [1]. Ionotropic receptors for GABA are ligand gated ion channels that on activation by GABA mediate fast neurotransmission by allowing a flow of chloride ions into the neuron, causing a hyperpolarization of the membrane and inhibiting further neuronal activity. A number of different ligands are known to modulate the function of the $\mathrm{GABA}_{\mathrm{A}}$ receptors, of which the benzodiazepines have attracted most attention due to their commercial importance. The benzodiazepine binding site is an allosteric modulatory site, different from the binding site of GABA itself, and is believed to be situated at the interface between two subunits of the pentameric receptor.

Full agonists acting at the benzodiazepine binding site have long been used as anxiolytics, but their applicability is limited due to adverse effects such as sedation, cognitive impairment and ataxia. The search for improved anxiolytics was triggered by the identification of $\mathrm{GABA}_{\mathrm{A}}$ receptors with different subunit compositions $\left(\alpha_{1-6}, \beta_{1-3}\right.$, $\gamma_{1-3}, \delta, \varepsilon, \pi$, and $\left.\theta\right)[2,3]$. The classical benzodiazepines affect $\mathrm{GABA}_{\mathrm{A}}$ receptors comprising $\beta, \gamma_{2}$ and either $\alpha_{1}$, $\alpha_{2}, \alpha_{3}$ or $\alpha_{5}$ subunits and it is generally believed that subtype selective ligands will discriminate between the pharmacological effects mediated by $\mathrm{GABA}_{\mathrm{A}}$ receptors. Studies with transgenic mice suggest that $\alpha_{1}$-containing receptors mediate sedative and anterograde amnesic effects, $\alpha_{2^{-}}$, and/or $\alpha_{3}$-containing receptors are involved in anxiolytic activity, while $\alpha_{5}$-containing receptors might be associated with cognition and memory [4,5]. A pharmacophore model of the benzodiazepine binding site [6] has been developed and refined as a result of a SAR study based on synthetic flavone derivatives $[7,8]$. The model has recently been applied for the identification and optimization of novel 4-quinolones and azaflavone derivatives as ligands at the $\mathrm{GABA}_{\mathrm{A}}$ receptors, with affinities as low as $0.05 \mathrm{nM}$ [9-11]. In addition, several other classes of compounds are known to bind to the benzodiazepine site, such as the 2-arylpyrazoloquinolines [12,13], $\beta$-carbolines [14], pyridodiindoles [15], pyrimidin-5(6H)-ones [16], cyclopyrrolones and quinolines [17]. In the present investigation new azoloquinolones, 3-arylisothiazolo[5,4-b]quinolin-4(9H)-ones and 3-arylisoxazolo[5,4-b]quinolin-4(9H)-ones, have been designed using the pharmacophore model, prepared by synthesis, and assayed.

\section{MATERIALS AND METHODS}

\subsection{Synthetic and Analytical Techniques}

Reagents and solvents (except THF) were used from commercial sources without purification. THF was distilled from sodium/benzophenone prior to use. ${ }^{1} \mathrm{H}$ and ${ }^{13} \mathrm{C}$ NMR were recorded at room temperature unless oth- 
erwise specified with a Bruker DR400 spectrometer. The spectra were recorded in $\mathrm{CDCl}_{3}, \mathrm{DMSO}-\mathrm{d}_{6}$, and $\mathrm{C}_{6} \mathrm{D}_{6}$, and the solvent signals (7.27 and 77.0, 2.50 and 39.5 or 7.18 and $128.1 \mathrm{ppm}$, respectively) were used as reference. Analytical thin layer chromatography (TLC) was performed on Kiselgel $60 \mathrm{~F}_{254}$ plates (Merck). Column chromatography was performed on $\mathrm{SiO}_{2}$ (Matrex LC-gel: 60A, 35-70 MY, Grace). Melting points (uncorrected) were determined with a Reichert microscope. EI mass spectra were recorded at $70 \mathrm{eV}$ with a Jeol SX102 spectrometer and ESI spectra were recorded with Micromass Q-TOF Micro.

\subsection{6-Methyl-2-(methylsulfanyl)-4H-3,1-benzo thiazin-4-one (1)}

To a solution of 2-amino-5-methylbenzoic acid (2.52 g, $16.7 \mathrm{mmol}$ ) and carbon disulfide (2.01 mL, $33.9 \mathrm{mmol})$ in $45 \mathrm{~mL}$ of dry 1,4-dioxane was added $\mathrm{NEt}_{3}(5.58 \mathrm{~mL}$, $40.0 \mathrm{mmol}$ ) and the mixture were stirred under $\mathrm{N}_{2}$ atmosphere at $5^{\circ} \mathrm{C}$ for 18 hours. Iodomethane $(1.14 \mathrm{~mL}$, $18.4 \mathrm{mmol}$ ) was added dropwise and the mixture was stirred as $5^{\circ} \mathrm{C}$ for 1 hour. The reaction was poured into $25 \mathrm{~mL}$ of an aqueous solution of $\mathrm{HCl}(1 \mathrm{M})$ and the mixture was concentrated to half its volume under reduced pressure and extracted three times with $75 \mathrm{~mL}$ of EtOAc. The combined organic layers were dried over $\mathrm{MgSO}_{4}$ and concentrated under reduced pressure. The residue was recrystallized from chloroform to give 5-methyl2-\{[(methylsulfanyl)carbonothioyl $]$ amino $\}$ benzoic acid as a yellow solid (3.25 g, 81\%). This (2.85 g, $11.8 \mathrm{mmol}$ ) was dissolved in $50 \mathrm{~mL}$ of acetic anhydride and heated at reflux for 1 hour. The mixture was cooled to room temperature and the precipitate was filtered off. The crude product was recrystallized from ethyl alcohol to give $\mathbf{1}$ as white needle-shaped crystals $(2.17 \mathrm{~g}, 83 \%)$ mp: $114^{\circ} \mathrm{C}$. ${ }^{1} \mathrm{H}$ NMR (400 MHz, $\left.\mathrm{CDCl}_{3}+5 \% \mathrm{MeOD}-\mathrm{d} 4\right) \delta 7.95(1 \mathrm{H}$, s), 7.57 (2H, bs), 2.70 (3H, s), 2.45 (3H, s); ${ }^{13} \mathrm{C}$ NMR $\left(100 \mathrm{MHz}, \mathrm{CDCl}_{3}+5 \%\right.$ MeOD-d4) $\delta$ 183.5, 162.3, 146.3, 138.0, 137.1, 129.8, 124.7, 119.1, 21.3, 14.2; HRMS (ESI): for $\mathrm{C}_{10} \mathrm{H}_{10} \mathrm{NOS}_{2}$ calcd: 224.0204; [M + H]; found: 224.0201 .

\subsection{Methyl \\ [2-((2Z)-3-hydroxy-3-phenyl-prop-2-enoyl)-4- methylphenyl]dithiocarbamate (2)}

A solution of 1.6 M n-BuLi (10.4 mL, $16.7 \mathrm{mmol})$ in hexanes was added to a solution of diisopropylamine (2.42 $\mathrm{mL}, 17.4 \mathrm{mmol}$ ) in $20 \mathrm{~mL}$ of THF under $\mathrm{N}_{2}$ atmosphere at $-78^{\circ} \mathrm{C}$. The solution was heated to $0^{\circ} \mathrm{C}$ and stirred for $5 \mathrm{~min}$ and then once again cooled to $-78^{\circ} \mathrm{C}$. To the resultant LDA solution was added a solution of acetophenone (2.28 mL, $16.7 \mathrm{mmol})$ in $5 \mathrm{~mL}$ of THF and the mixture was stirred for one hour. A solution of 1 in 20
$\mathrm{mL}$ of THF was slowly added and the mixture was slowly heated to $-30^{\circ} \mathrm{C}$ over a period of 3 hours, while monitored on TLC. The reaction was poured onto $35 \mathrm{~mL}$ of an aqueous solution of $\mathrm{HCl}(1 \mathrm{M})$ and the mixture was concentrated to half its volume. The residue was extracted with $100 \mathrm{~mL}$ of EtOAc and the organic layer was washed with Brine, dried over $\mathrm{MgSO}_{4}$ and concentrated under reduced pressure. The residue was dried under vacuum in order to remove a substantial fraction of unreacted acetophenone and the crude product was triturated from methanol to give 2 as a yellowish solid (88\%). On a general note for the purification of $\mathbf{2}$ - $\mathbf{6}$, somewhat increased yields were obtained if the residual solution was purified by chromatography, especially if the remaining amount of acetophenone is significant. Elution was done with a mixture of $n$-heptane/toluene/acetone (75:75:1). The reaction yielded 2 (88\%) as a yellow solid, mp: $129^{\circ} \mathrm{C} .{ }^{1} \mathrm{H}$ NMR $\left(400 \mathrm{MHz}, \mathrm{CDCl}_{3}\right) \delta 16.20(1 \mathrm{H}, \mathrm{s})$, 11.54 (1H, s), 8.44 (1H, d, $J=8.4 \mathrm{~Hz}), 7.75$ (2H, d, $J=$ $7.2 \mathrm{~Hz}), 7.39(1 \mathrm{H}, \mathrm{d}, J=1.4 \mathrm{~Hz}), 7.35(1 \mathrm{H}, \mathrm{d}, J=7.3$ $\mathrm{Hz}), 7.28(2 \mathrm{H}, \mathrm{t}, J=7.8 \mathrm{~Hz}), 7.13(1 \mathrm{H}, \mathrm{dd}, J=8.4$ and $1.4 \mathrm{~Hz}), 6.54(1 \mathrm{H}, \mathrm{s}), 2.20$ (3H, s), $2.16(3 \mathrm{H}, \mathrm{s}) ;{ }^{13} \mathrm{C}$ NMR (100 MHz, $\left.\mathrm{CDCl}_{3}\right) \delta 198.4,193.2,180.8,137.1$, 135.3, 133.9, 133.6, 132.9, 129.6, 129.0, 129.0, 127.2, 127.2, 126.7, 124.4, 95.5, 21.2, 18.7; HRMS (ESI): for $\mathrm{C}_{18} \mathrm{H}_{18} \mathrm{NO}_{2} \mathrm{~S}_{2}$ calcd: 344.0779; [M + H]; found: 344.0778.

\subsection{Methyl \\ \{2-[(2Z)-3-hydroxy-3-(4-methylphenyl)prop- 2-enoyl]-4-methylphenyl\}dithiocarbamate (3)}

Methyl\{2-[(2Z)-3-hydroxy-3-(4-methylphenyl)prop-2-en oyl]-4-methylphenyl \} dithiocarbamate (3) was prepared and purified according to the procedure described for $\mathbf{2}$, starting from 4'-methylacetophenone. 3 was obtained as a yellowish solid (2.18 g, 91\%), mp: $144^{\circ} \mathrm{C} .{ }^{1} \mathrm{H}$ NMR (400 MHz, DMSO-d6) $\delta 16.64(1 \mathrm{H}, \mathrm{s}), 11.69(1 \mathrm{H}, \mathrm{s}), 7.90(2 \mathrm{H}$, d, $J=8.2 \mathrm{~Hz}), 7.68(1 \mathrm{H}, \mathrm{d}, J=1.4 \mathrm{~Hz}), 7.44(1 \mathrm{H}, \mathrm{dd}, J=$ 8.1 and $1.4 \mathrm{~Hz}$ ), 7.37 (2H, d, $J=8.2 \mathrm{~Hz}), 7.37(1 \mathrm{H}, \mathrm{d}, J=$ $8.1 \mathrm{~Hz}), 6.83$ (1H, s), 2.57 (3H, s), 2.40 (3H, s), 2.39 (3H, s); ${ }^{13} \mathrm{C}$ NMR (100 MHz, DMSO-d6) $\delta 199.9,186.1,183,9$, 143.6, 137.7, 135.1, 132.8, 132.7, 131.6, 129.6, 129.5, 129.0, 127.2, 96.4, 21.2, 20.5, 18.1; HRMS (ESI): for $\mathrm{C}_{19} \mathrm{H}_{20} \mathrm{NO}_{2} \mathrm{~S}_{2}$ calcd: 358.0935; [M + H]; found: 358.0941.

\subsection{Methyl \\ \{2-[(2Z)-3-hydroxy-3-(4-methoxyphenyl)- prop-2-enoyl]-4-methylphenyl\} dithiocarbamate (4)}

Methyl\{2-[(2Z)-3-hydroxy-3-(4-methoxyphenyl)prop-2enoyl]-4-methylphenyl\}dithiocarbamate (4) was prepared and purified according to the procedure described for $\mathbf{2}$, starting from 4'-methoxyacetophenone. The reaction yielded 4 (85\%) as a yellow solid (mp: $\left.138^{\circ} \mathrm{C}\right) .{ }^{1} \mathrm{H}$ NMR 
(400 MHz, DMSO-d6) $\delta 16.80$ (1H, bs), 11.69 (1H, s), 7.99 (2H, d, $J=9.0 \mathrm{~Hz}), 7.68(1 \mathrm{H}, \mathrm{d}, J=1.5 \mathrm{~Hz}), 7.43$ (1H, dd, $J=8.1$ and $1.5 \mathrm{~Hz}), 7.37(1 \mathrm{H}, \mathrm{d}, J=8.1 \mathrm{~Hz})$, 7.09 (2H, d, $J=9.0 \mathrm{~Hz}), 6.80(1 \mathrm{H}, \mathrm{s}), 3.86(3 \mathrm{H}, \mathrm{s}), 2.57$ (3H, s), 2.40 (3H, s); ${ }^{13} \mathrm{C}$ NMR (100 MHz, DMSO-d6) $\delta$ 199.9, 184.6, 184.3, 163.3, 137.7, 135.0, 132.6, 132.6, 129.5, 129.4, 129.4, 129.0, 126.7, 114.3, 114.3, 95.9, 55.6, 20.6, 18.2; HRMS (ESI): for $\mathrm{C}_{19} \mathrm{H}_{20} \mathrm{NO}_{3} \mathrm{~S}_{2}$ calcd: 374.0885; [M + H]; found: 374.0885.

\subsection{Methyl \{2-[(2Z)-3-(4-bromophenyl)- 3-hydroxy-prop-2-enoyl]-4-methylphenyl\} dithiocarbamate (5)}

Methyl\{2-[(2Z)-3-(4-bromophenyl)-3-hydroxy-prop-2-enoyl]-4-methylphenyl \}dithiocarbamate (5) was prepared and purified according to the procedure described for $\mathbf{2}$, starting from 4'-bromoacetophenone. The reaction yielded $5(83 \%)$ as a yellow solid (mp: $\left.172{ }^{\circ} \mathrm{C}\right) .{ }^{1} \mathrm{H}$ NMR (300 $\left.\mathrm{MHz} \mathrm{CDCl}_{3}\right) \delta 16.18(1 \mathrm{H}, \mathrm{s}), 11.60(1 \mathrm{H}, \mathrm{s}), 8.61(1 \mathrm{H}, \mathrm{d}$, $J=8.5 \mathrm{~Hz}), 7.82$ (2H, d, $J=8.5 \mathrm{~Hz}), 7.63(2 \mathrm{H}, \mathrm{d}, J=8.5$ $\mathrm{Hz}), 7.59$ (1H, d, $J=1,5 \mathrm{~Hz}), 7.37(1 \mathrm{H}, \mathrm{d}, J=8.5 \mathrm{~Hz})$, 6.72 (1H, s), 2.69 (3H, s), 2.42 (3H, s); ${ }^{13} \mathrm{C}$ NMR (100 $\left.\mathrm{MHz}, \mathrm{CDCl}_{3}\right) \delta 198.7,193.2,179.6,137.0,135.4,133.7$, 132.9, 132.3, 132.3, 129.6, 128.6, 128.6, 127.7, 126.8, 124.7, 95.6, 21.2, 18.7; HRMS (ESI): for $\mathrm{C}_{18} \mathrm{H}_{17}$ $\mathrm{BrNO}_{2} \mathrm{~S}_{2}$ calcd: 421.9884; [M + H]; found: 421.9889 .

\section{7. (4-Hydroxy-6-methyl-2-thioxo-1, 2-dihydroquinolin-3-yl)- 4-phenyl-methanone (7)}

Keto-enol 2 (2.03 g, $5.93 \mathrm{mmol}$ ) was added to $100 \mathrm{~mL}$ of a $0.5 \mathrm{M}$ solution of sodium methoxide in methanol and the mixture was stirred at $0^{\circ} \mathrm{C}$ for 3 hours. A $1.0 \mathrm{M}$ solution of hydrochloric acid $(53 \mathrm{~mL})$ was poured onto the reaction and the mixture was concentrated to less than half its volume under reduced pressure. The obtained slurry was stirred for $30 \mathrm{~min}$ at room temperature and then filtrated. The precipitate was washed with $20 \mathrm{~mL}$ of water and $20 \mathrm{~mL}$ of methanol, subsequently, whereafter the crude product was precipitated from acetone. The reaction yielded 7 (94\%) as a yellow solid (mp: $\left.259^{\circ} \mathrm{C}\right)$. ${ }^{1} \mathrm{H}$ NMR (400 MHz, DMSO-d6) $\delta 7.88(1 \mathrm{H}, \mathrm{s}), 7.80(2 \mathrm{H}$, d, $J=7.4 \mathrm{~Hz}), 7.58(3 \mathrm{H}, \mathrm{m}), 7.47(2 \mathrm{H}, \mathrm{t}, J=7.4 \mathrm{~Hz})$, 2.41 (3H, s); ${ }^{13} \mathrm{C}$ NMR (100 MHz, DMSO-d6) $\delta 192.7$, 177.3, 156.1, 138.5, 137.0, 134.0, 133.6, 133.0, 133.0, 128.9, 128.9, 128.6, 128.6, 122.4, 122.2, 117.1, 116.4, 20.8; HRMS (ESI): for $\mathrm{C}_{17} \mathrm{H}_{14} \mathrm{NO}_{2} \mathrm{~S}$ calcd: 296.0745; [M $+\mathrm{H}]$; found: 296.0758 .

\section{8. (4-Hydroxy-6-methyl-2-thioxo-1, 2-dihydroquinolin-3-yl)(4-methylphenyl) methanone (8)}

(4-Hydroxy-6-methyl-2-thioxo-1,2-dihydroquinolin-3-yl) (4-methylphenyl)methanone (8) was prepared and purified according to the procedure described for 7 , starting from 3. 8 was obtained as a yellow solid (1.70 g, 93\%). mp: $280^{\circ} \mathrm{C}$; ${ }^{1} \mathrm{H}$ NMR (400 MHz, DMSO-d6) $\delta 13.17(1 \mathrm{H}$, s), $11.57(1 \mathrm{H}, \mathrm{bs}), 7.90(1 \mathrm{H}, \mathrm{bs}), 7.70(2 \mathrm{H}, \mathrm{d}, J=8.2 \mathrm{~Hz})$, $7.58(1 \mathrm{H}, \mathrm{d}, J=8.5 \mathrm{~Hz}), 7.53(1 \mathrm{H}, \mathrm{dd}, J=8.5$ and 1.5 $\mathrm{Hz}), 7.28(2 \mathrm{H}, \mathrm{d}, J=8.2 \mathrm{~Hz}), 2.40(3 \mathrm{H}, \mathrm{s}), 2.36(3 \mathrm{H}, \mathrm{s})$; ${ }^{13} \mathrm{C}$ NMR (100 MHz, DMSO-d6) $\delta$ 192.2, 177.4, 155.9, 143.4, 138.4, 134.7, 133.5, 133.0, 129.2, 129.2, 129.1, 129.1, 122.4, 122.4, 117.1, 116.4, 21.2, 20.8; HRMS (ESI): for $\mathrm{C}_{18} \mathrm{H}_{16} \mathrm{NO}_{2} \mathrm{~S}$ calcd: 310.0902 ; [M $+\mathrm{H}$ ]; found: 310.0902 .

\section{9. (4-Hydroxy-6-methyl-2-thioxo-1, 2-dihydroquinolin-3-yl)(4-methoxyphenyl) methanone (9)}

(4-Hydroxy-6-methyl-2-thioxo-1,2-dihydroquinolin-3-yl) (4-methoxyphenyl)methanone (9) was prepared and purified according to the procedure described for $\mathbf{7}$, starting from 4 . The reaction yielded $9(93 \%)$ as a yellow solid (mp: $\left.260^{\circ} \mathrm{C}\right) .{ }^{1} \mathrm{H}$ NMR (400 MHz, DMSO-d6) $\delta 12.05$ (1H, bs), $7.75(1 \mathrm{H}, \mathrm{d}, J=1.5 \mathrm{~Hz}), 7.72(2 \mathrm{H}, \mathrm{dt}, J=8.9$ and $2.8 \mathrm{~Hz}), 7.44(1 \mathrm{H}, \mathrm{d}, J=8.4 \mathrm{~Hz}), 7.37(1 \mathrm{H}, \mathrm{dd}, J=$ 8.4 and $1.5 \mathrm{~Hz}$ ), $6.95(2 \mathrm{H}, \mathrm{dt}, J=8.9$ and $2.8 \mathrm{~Hz}),{ }^{13} \mathrm{C}$ NMR (100 MHz, DMSO-d6) $\delta$ 193.6, 175.3, 162.7, 161.8, 138.7, 132.6, 131.6, 131.3, 131.3, 123.4, 121.8, 119.9, 116.2, 113.6, 113.6, 55.5, 20.8; HRMS (ESI): for $\mathrm{C}_{18} \mathrm{H}_{16} \mathrm{NO}_{3} \mathrm{~S}$ calcd: 326.0851; [M + H]; found: 326.0849.

\subsection{0. (4-Bromophenyl) \\ (4-hydroxy-6-methyl-2-thioxo-1,2- dihydroquinolin-3-yl) methanone (10)}

(4-Bromophenyl)(4-hydroxy-6-methyl-2-thioxo-1,2-dihy droquinolin-3-yl) methanone (10) was prepared and purified according to the procedure described for $\mathbf{7}$, starting from $\mathbf{5}$. The reaction yielded $\mathbf{1 0}(98 \%)$ as a yellow solid (mp: $\left.275^{\circ} \mathrm{C}\right) .{ }^{1} \mathrm{H}$ NMR $(400 \mathrm{MHz}$, DMSO-d6) $\delta 7.92(1 \mathrm{H}$, s), $7.73(2 \mathrm{H}, \mathrm{d}, J=8.5 \mathrm{~Hz}), 7.68$ (2H, d, $J=8.5 \mathrm{~Hz}), 7.58$ (1H, d, $J=8.5 \mathrm{~Hz}), 7.56$ (1H, d, $J=8.5 \mathrm{~Hz}), 2,41$ (3H, s); ${ }^{13} \mathrm{C}$ NMR (100 MHz, DMSO-d6) $\delta 191.8,177.0,156.5$, 138.5, 136.2, 133.7, 133.7, 133.0, 133.0, 131.8, 130.9, 127.0, 122.5, 121.5, 117.2, 116.4, 20.8; HRMS (ESI): for $\mathrm{C}_{17} \mathrm{H}_{13} \mathrm{BrNO}_{2} \mathrm{~S}$ calcd: 373.9850; [M + H]; found: 373.9849 .

\subsection{1. (4-Hydroxy-6-methyl-2-thioxo-1, 2-dihydroquinolin-3-yl)(4-nitrophenyl) methanone (11)}

(4-Hydroxy-6-methyl-2-thioxo-1,2-dihydroquinolin-3-yl) (4-nitrophenyl)methanone (11) was prepared and purified according to the procedure described for 2 , starting from 4'-nitroacetophenone. The reaction yielded a mixture of the keto-enol compounds $\mathbf{6}$ and 11, which was 
applied to the condition described for the synthesis of $\mathbf{7}$ for a complete conversion to $\mathbf{1 1}$. The two-step reaction yielded 11 (37\%) as a yellow solid (mp: $\left.247^{\circ} \mathrm{C}\right) .{ }^{1} \mathrm{H}$ NMR (400 MHz, DMSO-d6,) $\delta 13.42$ (1H, bs), 11.57 (1H, s), 8.29 (2H, d, $J=8.7 \mathrm{~Hz}), 7.92(2 \mathrm{H}, \mathrm{d}, J=8.7 \mathrm{~Hz})$, $7.80(1 \mathrm{H}, \mathrm{s}), 7.50(1 \mathrm{H}, \mathrm{dd}, J=8.4$ and $1.6 \mathrm{~Hz}), 7.24(1 \mathrm{H}$, d, $J=8.4 \mathrm{~Hz}), 2.37(3 \mathrm{H}, \mathrm{s}) ;{ }^{13} \mathrm{C}$ NMR $(100 \mathrm{MHz}$, DMSO-d6) $\delta 191.4,176.9,157.0,149.7,142.0,138.7$, 133.9, 133.2, 130.0, 130.0, 123.9, 123.9, 122.6, 121.0, 117.3, 116.5, 20.8; HRMS (ESI): for $\mathrm{C}_{17} \mathrm{H}_{13} \mathrm{~N}_{2} \mathrm{O}_{4} \mathrm{~S}$ calcd: 341.0596; [M + H]; found: 341.0601.

\subsection{6-Methyl-3-phenylisothiazolo [5,4-b]quinolin-4(9H)-one (12)}

To a solution of 7 (76 mg, $0.259 \mathrm{mmol})$ in $25 \mathrm{~mL}$ of methanol was added a solution of hydroxylamine-Osulfonic acid (102.6 mg, $0.907 \mathrm{~mol}$ ) and lithium hydroxide (38.1 mg, $0.907 \mathrm{mmol}$ ) in $3 \mathrm{~mL}$ of methanol and the mixture was stirred at room temperature for 30 hours. The reaction mixture was concentrated under reduced pressure and applied to flash chromatography. Elution with heptane/EtOAc (3:1) yielded 12 (92\%) as a white solid (mp: $\left.302^{\circ} \mathrm{C}\right) .{ }^{1} \mathrm{H}$ NMR (400 MHz, DMSO-d6) 12.85 (1H, s), 8.02 (1H, bs), 7.81 (2H, m), 7.61 (1H, dd, $J=8.3$ and $1.3 \mathrm{~Hz}), 7.47(4 \mathrm{H}, \mathrm{m}), 2.43(3 \mathrm{H}, \mathrm{s}) ;{ }^{13} \mathrm{C} \mathrm{NMR}$ (100 MHz, DMSO-d6) $\delta 172.6,166.7,166.0,137.7$, 135.5, 134.5, 132.3, 129.5, 129.0, 127.4, 125.5, 123.6, 117.3, 117.3, 20.6; HRMS (ESI): for $\mathrm{C}_{17} \mathrm{H}_{13} \mathrm{~N}_{2} \mathrm{OS}$ calcd: 293.0749 [M + H]; found: 293.0763.

\subsection{6-Methyl-3-(4-methylphenyl) isothiazolo[5,4-b]quinolin-4(9H)-one (13)}

6-Methyl-3-(4-methylphenyl)isothizolo[5,4-b]quinolin-4 (9H)-one (13) was prepared and purified according to the procedure described for 12, starting from 8. 13 was obtained as a white solid (44 mg, 55\%). mp: $330{ }^{\circ} \mathrm{C} ;{ }^{1} \mathrm{H}$ NMR (400 MHz, DMSO-d6) $\delta 12.80(1 \mathrm{H}, \mathrm{s}), 8.02(1 \mathrm{H}$, bs), $7.73(2 \mathrm{H}, \mathrm{d}, J=7.9 \mathrm{~Hz}), 7.61(1 \mathrm{H}$, dd, $J=8.4$ and $1.5 \mathrm{~Hz}), 7.45(1 \mathrm{H}, \mathrm{d}, J=8.4 \mathrm{~Hz}), 7.26(2 \mathrm{H}, \mathrm{d}, J=7.9$ $\mathrm{Hz}), 2.43$ (3H, s), $2.39(3 \mathrm{H}, \mathrm{s}) ;{ }^{13} \mathrm{C}$ NMR (100 MHz, DMSO-d6) $\delta 172.7,166.8,166.0,138.6,137.7,134.5$, 132.8, 132.3, 129.4, 129.4, 128.0, 128.0, 125.6, 123.6, 117.3, 117.3, 21.0, 20.7; HRMS (ESI): for $\mathrm{C}_{18} \mathrm{H}_{15} \mathrm{~N}_{2} \mathrm{OS}$ calcd: 307.0905; [M + H]; found: 307.0908.

\subsection{3-(4-Methoxyphenyl)-6-methylisothiazolo [5,4-b]quinolin-4(9H)-one (14)}

3-(4-Methoxyphenyl)-6-methylisothiazolo[5,4- $b$ ]quinoli $\mathrm{n}-4(9 H)$-one $(14)$ was prepared and purified according to the procedure described for $\mathbf{1 2}$, starting from $\mathbf{9}$. The reaction yielded $14(62 \%)$ as a white solid (mp: $\left.318^{\circ} \mathrm{C}\right) .{ }^{1} \mathrm{H}$ NMR (400 MHz, DMSO-d6) $\delta 8.03$ (1H, s), 7.83 (2H, d,
$J=8.4 \mathrm{~Hz}), 7.57$ (1H, d, $J=8.2 \mathrm{~Hz}), 7.44$ (1H, d, $J=8.2$ $\mathrm{Hz}), 7.00$ (2H, d, $J=8.4 \mathrm{~Hz}$ ), 3.83 (3H, s), 2.43 (3H, s); ${ }^{13} \mathrm{C}$ NMR (100 MHz, DMSO-d6) $\delta 172.7,167.2,165.7$, 160.0 , 138.1, 134.4, 132.1, 131.0, 131.0, 128.2, 125.6, 123.7, 117.6, 117.1, 112.7, 112.7, 55.2, 20.7; HRMS (ESI): for $\mathrm{C}_{18} \mathrm{H}_{15} \mathrm{~N}_{2} \mathrm{OS}$ calcd: 323.0854; [M + H]; found: 323.0851 .

\subsection{3-(4-Bromophenyl)-6-methylisothiazolo [5,4-b]quinolin-4(9H)-one (15)}

3-(4-Bromophenyl)-6-methylisothiazolo[5,4-b]quinolin$4(9 H)$-one (15) was prepared and purified according to the procedure described for 12, starting from $\mathbf{1 0}$. The reaction yielded $15(77 \%)$ as a white solid (mp: $\left.357^{\circ} \mathrm{C}\right)$. ${ }^{1} \mathrm{H}$ NMR (400 MHz, DMSO-d6) $\delta 12.95$ (1H, s), 8.02 $(1 \mathrm{H}, \mathrm{d}, J=1.9 \mathrm{~Hz}), 7.79(2 \mathrm{H}, \mathrm{dt}, J=8.4$ and $1.7 \mathrm{~Hz})$, 7.67 (2H, dt, $J=8.4$ and $1.7 \mathrm{~Hz}), 7.61(1 \mathrm{H}$, dd, $J=8.4$ and $1.9 \mathrm{~Hz}$ ), 7.47 (1H, d, $J=8.4 \mathrm{~Hz}), 2.43(3 \mathrm{H}, \mathrm{s}) ;{ }^{13} \mathrm{C}$ NMR (100 MHz, DMSO-d6) $\delta$ 172.7, 166.8, 164.7, $137.7,134.7,134.6,132.5,131.6,131.6,130.4,130.4$, 125.5, 123.5, 122.8, 117.4, 117.2, 20.6; HRMS (ESI): for $\mathrm{C}_{17} \mathrm{H}_{12} \mathrm{BrN}_{2} \mathrm{OS}$ calcd: 370.9854; [M + H]; found: 370.9857.

\subsection{6-Methyl-3-(4-nitrophenyl)-isothiazolo [5,4-b]quinolin-4(9H)-one (16)}

6-Methyl-3-(4-nitrophenyl)-isothiazolo[5,4-b]quinolin-4( $9 H$ )-one (16) was prepared and purified according to the procedure described for $\mathbf{1 2}$, starting from $\mathbf{1 1}$. The reaction yielded 16 (81\%) as a white solid (mp: $\left.343^{\circ} \mathrm{C}\right) .{ }^{1} \mathrm{H}$ NMR (400 MHz, DMSO-d6) $\delta 8.32$ (2H, d, $J=8.9 \mathrm{~Hz}$ ), $8.11(2 \mathrm{H}, \mathrm{d}, J=8.9 \mathrm{~Hz}), 8.03(1 \mathrm{H}, \mathrm{d}, J=1.8 \mathrm{~Hz}), 7.61$ (1H, dd, $J=8.3$ and $1.8 \mathrm{~Hz}), 7.49(1 \mathrm{H}, \mathrm{d}, J=8.3 \mathrm{~Hz})$, 2.43 (3H, s); ${ }^{13} \mathrm{C}$ NMR (100 MHz, DMSO-d6) $\delta$ 172.7, 167.2, 163.6, 147.6, 141.5, 138.1, 134.7, 132.4, 130.9, 130.9, 125.4, 123.5, 122.6, 122.6, 117.8, 117.3, 20.7; HRMS (ESI): for $\mathrm{C}_{17} \mathrm{H}_{12} \mathrm{~N}_{3} \mathrm{O}_{3} \mathrm{~S}$ calcd: 338.0599; [M + H]; found: 338.0599.

\subsection{6-Methyl-3-(4-methylbenzoyl)-2- (methylsulfanyl)quinolin-4(1H)-one (17)}

To a solution of $8(0.800 \mathrm{~g}, 2.59 \mathrm{mmol})$ in $100 \mathrm{~mL}$ of methyl alcohol was added N,N-diisopropylethylamine (0.451 $\mathrm{mL}, 2.59 \mathrm{mmol})$ and the mixture was stirred at room temperature for $15 \mathrm{~min}$. Dimethyl sulfate $(0.246$ $\mathrm{mL}, 2.59 \mathrm{mmol}$ ) was added and the solution was stirred for additionally 2 hours at room temperature. The mixture was concentrated and a saturated solution of $200 \mathrm{~mL}$ of Brine was added. The mixture was extracted with 300 $\mathrm{mL}$ of EtOAc, the organic layer was dried over $\mathrm{MgSO}_{4}$ and concentrated under reduced pressure. The crude product was precipitated from acetone to give $\mathbf{1 7}$ as a white solid (0.804 g, 96\%). mp: $199^{\circ} \mathrm{C} ;{ }^{1} \mathrm{H}$ NMR (400 
MHz, DMSO-d6) $\delta 11.70(1 \mathrm{H}, \mathrm{s}), 7.84$ (1H, bs), 7.70 (2H, d, $J=8.1 \mathrm{~Hz}), 7.65(1 \mathrm{H}, \mathrm{d}, J=8.5 \mathrm{~Hz}), 7.53(1 \mathrm{H}$, dd, $J=8.5$ and $1.9 \mathrm{~Hz}), 7.27(2 \mathrm{H}, \mathrm{d}, J=8.1 \mathrm{~Hz}), 2.57$ (3H, s), $2.40(3 \mathrm{H}, \mathrm{s}), 2.36(3 \mathrm{H}, \mathrm{s}) ;{ }^{13} \mathrm{C}$ NMR (100 MHz, DMSO-d6) $\delta$ 194.2, 173.4, 147.3, 143.6, 139.1, 134.8, 133.6, 133.4, 129.2, 129.2, 129.1, 129.1,124.3, 124.0, 121.9, 118.4, 21.2, 20.7, 16.0; HRMS (ESI): for $\mathrm{C}_{19} \mathrm{H}_{18} \mathrm{NO}_{2} \mathrm{~S}$ calcd: 324.1058; [M + H]; found: 324.1058.

\subsection{6-Methyl-2-methylsulfanyl-3- (4-nitrobenzoyl)quinolin-4(1H)-one (18)}

6-Methyl-2-methylsulfanyl-3-(4-nitrobenzoyl)quinolin-4 (1H)-one (18) was prepared and purified according to the procedure described for 17 , starting from 11 . The reaction yielded $18(86 \%)$ as a white solid [mp: $280^{\circ} \mathrm{C}$ (decomp.)]. ${ }^{1} \mathrm{H}$ NMR (400 MHz, DMSO-d6) $\delta 11.69(1 \mathrm{H}$, bs), 8.28 (2H, dt, $J=8.95$ and $2.2 \mathrm{~Hz}), 7.96(2 \mathrm{H}, \mathrm{dt}, J=$ 8.95 and $2.2 \mathrm{~Hz}), 7.80$ (1H, d, $J=1.9 \mathrm{~Hz}), 7.69(1 \mathrm{H}, \mathrm{d}, J$ $=8.5 \mathrm{~Hz}), 7.57(1 \mathrm{H}, \mathrm{dd}, J=8.5$ and $1.9 \mathrm{~Hz}), 2.64(3 \mathrm{H}, \mathrm{s})$, 2.40 (3H, s); ${ }^{13} \mathrm{C}$ NMR (100 MHz, DMSO-d6) $\delta$ 193.8, 173.8, 151.1, 149.6, 142.9, 138.7, 133.9, 133.9, 129.9, 129.9, 124.6, 124.2, 123.9, 123.9, 119.7, 118.5, 20.7, 15.7; HRMS (ESI): for $\mathrm{C}_{18} \mathrm{H}_{15} \mathrm{~N}_{2} \mathrm{O}_{4} \mathrm{~S}$ calcd: 355.0753; [M+ H]; found: 355.0751 .

\subsection{6-Methyl-3-phenyl-isoxazolo[5,4-b] quinolin-4(9H)-one (19)}

A mixture of hydroxylamine hydrochloride (22.6 mg, $0.325 \mathrm{mmol}$ ) and sodium acetate (26.6 mg, $0.325 \mathrm{mmol}$ ) was stirred in $3 \mathrm{~mL}$ of ethyl alcohol for $30 \mathrm{~min}$. The precipitate was filtered off and the clear hydroxylamine solution was added to 7 (19.2 $\mathrm{mg}, 0.065 \mathrm{mmol})$ and the mixture was heated at reflux for 18 hours. The reaction mixture was concentrated under reduced pressure and to the crude oxime was added Amberlyst 15 (20 mg) and 2 $\mathrm{mL}$ of acetonitrile and the mixture was heated at reflux under vigorous stirring for 8 hours. The mixture was cooled to room temperature and filtrated through a porous glass filter in order to remove the Amberlyst resin. The residue was purified by chromatography. Elution with $n$-heptan/EtOAc (3:1) gave 19 (20\%) as a white solid (mp: $\left.256^{\circ} \mathrm{C}\right) .{ }^{1} \mathrm{H}$ NMR (400 MHz, DMSO-d6) $\delta$ 8.32 (2H, m), 8.03 (1H, s), 7.57 (4H, m), $7.48(1 \mathrm{H}, \mathrm{d}, J=$ $8.3 \mathrm{~Hz}), 2.43$ (3H, s); ${ }^{13} \mathrm{C}$ NMR (100 MHz, DMSO-d6) $\delta$ 172.4, 165.7, 159.9, 135.8, 134,5, 132.6, 130.8, 129.1, 129.1, 128.5, 128.5, 127.5, 125.6, 124.1, 118.0, 98.5, 20.6; HRMS (ESI): for $\mathrm{C}_{17} \mathrm{H}_{13} \mathrm{~N}_{2} \mathrm{O}_{2}$ calcd: 277.0977; [M $+\mathrm{H}]$; found: 277.0976 .

\subsection{6-Methyl-3-(4-methylphenyl)isoxazolo [5,4-b]quinolin-4(9H)-one (20)}

6-Methyl-3-(4-methylphenyl)isoxazolo[5,4-b]quinolin-4 $(9 H)$-one (20) was prepared and purified according to the procedure described for 19, starting from 17. 20 was obtained as a white solid (5 mg, 26\%). mp: $261^{\circ} \mathrm{C} ;{ }^{1} \mathrm{H}$ NMR (400 MHz, DMSO-d6) $\delta 13.49(1 \mathrm{H}, \mathrm{s}), 8.25(2 \mathrm{H}$, d, $J=8.0 \mathrm{~Hz}), 8.04(1 \mathrm{H}, \mathrm{d}, J=1.5 \mathrm{~Hz}), 7.59(1 \mathrm{H}, \mathrm{d}, J=$ $8.2 \mathrm{~Hz}$ and $1.5 \mathrm{~Hz}), 7.48(1 \mathrm{H}, \mathrm{d}, J=8.2 \mathrm{~Hz}), 7.36(2 \mathrm{H}, \mathrm{d}$, $J=8.0 \mathrm{~Hz}), 2.43(3 \mathrm{H}, \mathrm{s}), 2.40(3 \mathrm{H}, \mathrm{s}) ;{ }^{13} \mathrm{C}$ NMR $(100$ MHz, DMSO-d6) $\delta$ 172.4, 165.7, 159.8, 140.6, 135.8, $134.4,132.5,129.1,129.1,129.0,129.0,125.6,124.7$, 124.1, 118.0, 98.5, 21.1, 20.6; HRMS (ESI): for $\mathrm{C}_{18} \mathrm{H}_{15} \mathrm{~N}_{2} \mathrm{O}_{2}$ calcd: 291.1134; [M + H]; found: 291.1139.

\subsection{6-Methyl-3-(4-nitrophenyl)-isoxazolo [5,4-b]quinolin-4(9H)-one (21)}

6-Methyl-3-(4-nitrophenyl)isoxazolo[5,4-b]quinolin-4(9H)one (21) was prepared and purified according to the procedure described for 19 , starting from 18 . The reaction yielded 21 (35\%) as a white solid [mp: $295^{\circ} \mathrm{C}$ (decomp.)]. ${ }^{1} \mathrm{H}$ NMR (400 MHz, DMSO-d6) $\delta 8.65$ (2H, dt, $J=9.1$ and $2.3 \mathrm{~Hz}), 8.42(2 \mathrm{H}, \mathrm{dt}, J=9.1$ and $2.3 \mathrm{~Hz}), 8.06(1 \mathrm{H}$, d, $J=2.1 \mathrm{~Hz}) 7.63(1 \mathrm{H}$, dd, $J=8.4$ and $2.1 \mathrm{~Hz}), 7.51$ $(1 \mathrm{H}, \mathrm{d}, J=8.4 \mathrm{~Hz}), 2.44$, $(3 \mathrm{H}, \mathrm{s}) ;{ }^{13} \mathrm{C} \mathrm{NMR}(100 \mathrm{MHz}$, DMSO-d6) $\delta 172.4,166.0,158.4,148.7,136.1,134.7$, 133.8, 132.7, 130.4, 130.4, 125.5, 124.0, 123.7, 123.7, 121.5, 118.3, 98.5, 20.6; HRMS (ESI): for $\mathrm{C}_{17} \mathrm{H}_{12} \mathrm{~N}_{3} \mathrm{O}_{4}$ calcd: 322.0828; [M + H]; found: 322.0832.

\subsection{Benzodiazepine Receptor Binding in Vitro}

Binding of ${ }^{3} \mathrm{H}$-Flumazenil $(87 \mathrm{Ci} / \mathrm{mmol}$ ) to rat cortical membranes and to a membrane suspension of HEK 293 cells expressing human $\alpha_{1} \beta_{3} \gamma_{2}, \alpha_{2} \beta_{3} \gamma_{2}, \alpha_{3} \beta_{3} \gamma_{2}$, or $\alpha_{5} \beta_{3} \gamma_{2}$ GABA $_{\mathrm{A}}$ receptors was done following methods previously described by Dekermendjian et al. [7]. In brief: Tissue is homogenized in $20 \mathrm{~mL}$ Tris, HCl (30 $\mathrm{mM}, \mathrm{pH}$ 7.4) using an Ultra-Turrax homogenizer. The suspensions are centrifuged at 27,000 g for $15 \mathrm{~min}$ followed by three centrifugations resuspensions cycles. The washed pellet is resuspended in $20 \mathrm{~mL}$ buffer, incubated at $37^{\circ} \mathrm{C}$ for $30 \mathrm{~min}$ and then centrifuged for $10 \mathrm{~min}(27,000 \mathrm{~g})$. The pellet is washed once and the final pellet is resuspended in $30 \mathrm{~mL}$ Tris, $\mathrm{HCl}$ buffer (50 mM, pH 7.1) and stored at $-20^{\circ} \mathrm{C}$ until use. For binding studies frozen membrane suspensions were thawed and centrifuged (27,000 g, $10 \mathrm{~min})$. The pellet was resuspended into Tris, citrate buffer $(50 \mathrm{mM}, \mathrm{pH}$ 7.1) at a tissue concentration: cortex preparation ca 50 $\mu \mathrm{g}$ protein/0.55 $\mathrm{mL}$ assay (1 $\mathrm{mg}$ original tissue/0.55 $\mathrm{mL}$ assay) and HEK cells ca $25 \mu \mathrm{g}$ protein per 0.55 $\mathrm{mL}$ assay. Aliquots of $0.5 \mathrm{ml}$ membrane preparation are added to $25 \mu \mathrm{l}$ of ${ }^{3} \mathrm{H}$-Flumazenil solution (1 nM final concentration) and $25 \mu \mathrm{l}$ containing test substance and incubated at an ice-bath $\left(0^{\circ} \mathrm{C}-4^{\circ} \mathrm{C}\right)$ for 40 min. The incubated samples were added $5 \mathrm{~mL}$ ice-cold

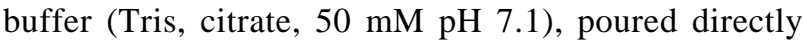


onto Whatman GF/C glass fiber filters under suction and immediately washed with $5 \mathrm{~mL}$ ice-cold buffer. Nonspecific binding was determined by adding Clonazepam ( $1 \mu \mathrm{M}$ final concentration) to separate samples. Protein was estimated by conventional protein assay method using Bovine serum albumin as standard. IC $_{50}$ values were determined using 4 - 6 different concentrations of test substance. $K_{i}$ values were calculated according to $K_{i}=\mathrm{IC}_{50} /\left(1+(\mathrm{L}) / K_{D}\right)$, $(\mathrm{L})$ is the concentration $(\mathrm{nM})$ of ${ }^{3} \mathrm{H}$-Flumazenil; $K_{D}$ is binding affinity constant of ${ }^{3} \mathrm{H}$-Flumazenil (1.6 nM).

\subsection{Computational Methods}

Conformational analysis and calculations of the electrostatic potential on Van der Waals surfaces were performed using density functional theory B3LYP/6-31G* utilizing Spartan 10 (Wavefunction Inc.). In the search for lead targets at the BZD binding site, representative structures were fit into the pharmacophore model using the program Catalyst [18].

\section{RESULTS}

\subsection{Chemical Synthesis}

All 3-arylisothiazolo[5,4-b]quinolin-4(9H)-ones and 3arylisoxazolo[5,4-b]quinolin-4(9H)-ones prepared and presented in this investigation are to our knowledge new compounds. For all target compounds, an unambiguous structure determination was performed using COSY, HMQC, HMBC and NOESY NMR experiments as well as high resolution mass spectrometry.

$4 H$-Benzo[ $d][1,3]$ thiazin-4-one (1) was synthesized by the addition of carbon disulfide to 5-methyl anthranilic acid followed by methylation of the sulfur and thiolactone formation in acetic anhydride [19]. The addition of different acetophenones to $\mathbf{1}$ afforded the keto-enols $\mathbf{2}$ - $\mathbf{6}$, which were recyclized to give the corresponding thione derivatives 7 - 11. Under the conditions used for the preparation of compound $\mathbf{6}$ it was partially transformed into thione 11, consequently the mixture was used directly in the following step and $\mathbf{6}$ was not isolated. The 3 -arylisothiazolo $[5,4-b]$ quinolin-4 $(9 H)$-one derivatives 12 - 16 were prepared by treatment of the thiones $\mathbf{7}$ - $\mathbf{1 1}$ with hydroxylamine-O-sulfonic acid [20] (Scheme 1). The 3-arylisoxazolo[5,4-b]quinolin-4(9H)-one derivatives 19 - 21 were prepared by treating the thione $\mathbf{7}$ and the $S$-methylated derivatives of $\mathbf{8}$ and $\mathbf{1}$, the quinolones 17 and 18, with hydroxylamine in ethanol followed by Amberlyst 15 in acetonitrile (Scheme 2). Both routes resulted in modest yields of the isoxazoloquinolines, presumably due to competing side reactions. Under the conditions employed for the cyclization of the oxime it is known that oxazolo[4,5-c]quinolones may be formed by a Beckmann rearrangement, while isoxazolo[ $[4,5-c]$ qui-

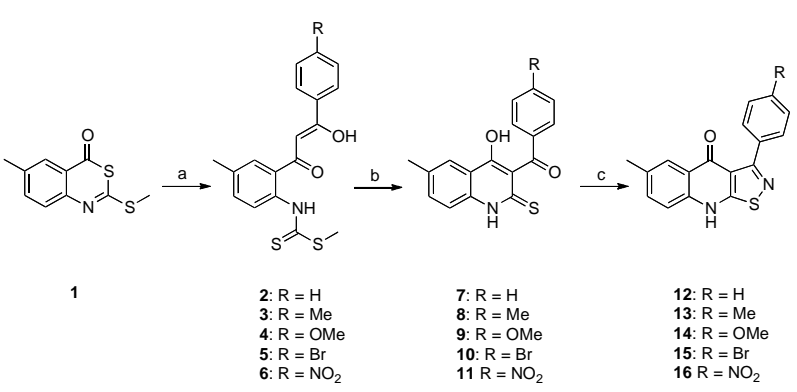

Scheme 1. Conditions: (a) LDA, 4'-acetophenones, THF, $-78^{\circ} \mathrm{C}, 1 \mathrm{~h}$, then $1,-78^{\circ} \mathrm{C}$ to $-30^{\circ} \mathrm{C}, 3 \mathrm{~h}$ (yields $75 \%-91 \%$ ); (b) $\mathrm{NaOMe}, \mathrm{MeOH}, 0^{\circ} \mathrm{C}$, $3 \mathrm{~h}$ (yields $89 \%$ - 98\% for 7 - 10; $37 \%$ for 11); (c) $\mathrm{H}_{2} \mathrm{NOSO}_{3} \mathrm{H}, \mathrm{LiOH}, \mathrm{MeOH}$, rt, 24 h (yields $55 \%$ $92 \%)$.
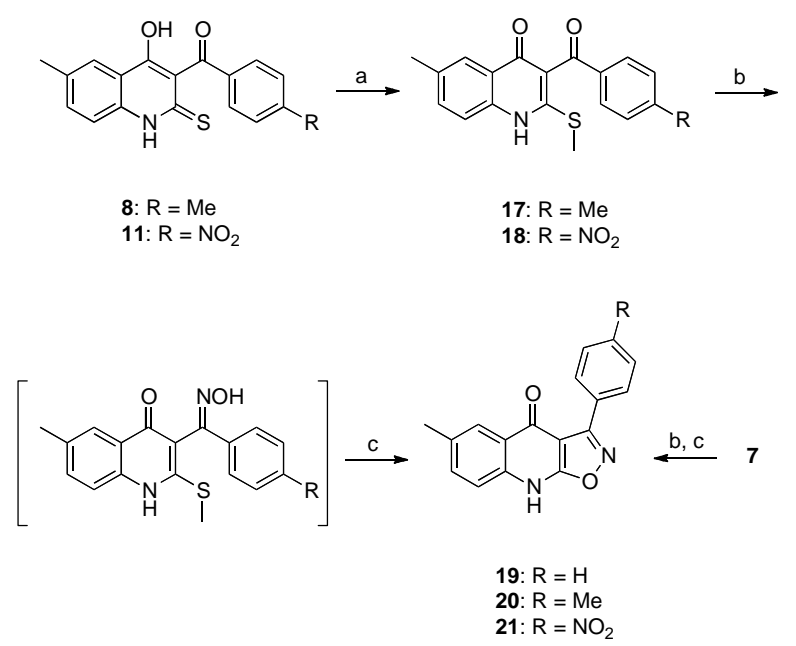

Scheme 2. Conditions: (a) DIPEA, $(\mathrm{MeO})_{2} \mathrm{SO}_{2}, \mathrm{MeOH}$, rt., 2 h (yields $86 \%$ - 98\%); (b) $\mathrm{H}_{2} \mathrm{NOH} \cdot \mathrm{HCl}, \mathrm{NaOAc}$, EtOH, reflux, 18 h; (c) Amberlyst 15, MeCN, reflux, 8 h (yields 20\% for 19, $26 \%$ for $\mathbf{2 0}$ and $35 \%$ for $\mathbf{2 1}$, over two steps).

nolines can be the product of a cyclization at the 4-position of the quinolone scaffold [21,22].

\subsection{Receptor Binding}

Affinities for the BZD binding site were determined in vitro by displacement of $\left[{ }^{3} \mathrm{H}\right]$-Flumazenil in rat cortical tissue (Table 1). Subtype affinities were investigated with compounds 13 and 19, on recombinant $\alpha_{1} \beta_{3} \gamma_{2}, \alpha_{2} \beta_{3} \gamma_{2}$, $\alpha_{3} \beta_{3} \gamma_{2}$, and $\alpha_{5} \beta_{3} \gamma_{2}$ receptor subtypes expressed in HEK 293 cell lines (Table 2).

\section{DISCUSSION}

The 3-arylisothiazoloquinolones and 3-arylisooxazoloquinolones seem to fulfill the basic requirements necessary for efficient binding to the benzodiazepine binding site, as indicated by the positioning of compounds $\mathbf{1 3}$ and 20 into the pharmacophore model (Figures $\mathbf{1}$ and 2). They can accept a hydrogen bond from $\mathrm{H} 1$ to $\mathrm{N}-2$, donate 
Table 1. $K_{i}$ Values of azoloquinolines tested on ${ }^{3} \mathrm{H}$-Flumazenil binding in vitro to rat cortical membranes.

\begin{tabular}{cc}
\hline Compound & $\boldsymbol{K}_{\boldsymbol{i}}(\mathrm{nM})^{a}$ \\
\hline $\mathbf{1 2}$ & $26 \pm 3$ \\
$\mathbf{1 3}$ & $1.9 \pm 0.7$ \\
$\mathbf{1 4}$ & $2.1 \pm 0.1$ \\
$\mathbf{1 5}$ & $5.3 \pm 1.0$ \\
$\mathbf{1 6}$ & $5.8 \pm 0.8$ \\
$\mathbf{1 9}$ & $17 \pm 7$ \\
$\mathbf{2 0}$ & $23 \pm 3$ \\
$\mathbf{2 1}$ & $200 \pm 21$ \\
\hline
\end{tabular}

${ }^{a}$ Each $K_{i}$ value is the mean of $\pm \mathrm{SD}$ of three determinations.

Table 2. The affinity of selected compounds tested on 3HFlumazenil binding to $\alpha_{1} \beta_{3} \gamma_{2 \mathrm{~s}}, \alpha_{2} \beta_{3} \gamma_{2 \mathrm{~s}}, \quad \alpha_{3} \beta_{3} \gamma_{2 \mathrm{~s}}$, and $\alpha_{5} \beta_{3} \gamma_{2}$ GABAA receptor subtypes.

\begin{tabular}{lllll}
\hline Compound & $K_{\mathrm{i}} \alpha_{1}(\mathrm{nM})^{a}$ & $K_{\mathrm{i}} \alpha_{2}(\mathrm{nM})^{a}$ & $K_{\mathrm{i}} \alpha_{3}(\mathrm{nM})^{a}$ & $K_{\mathrm{i}} \alpha_{5}(\mathrm{nM})^{a}$ \\
\hline $\mathbf{1 3}$ & $2.6 \pm 0.9$ & $15 \pm 4.0$ & $7.6 \pm 1.7$ & $7.1 \pm 1.9$ \\
$\mathbf{1 9}$ & $25 \pm 5.7$ & $310 \pm 120$ & $130 \pm 34$ & $230 \pm 36$ \\
\hline
\end{tabular}

${ }^{a}$ Each Ki value is the mean \pm SD of three determinations.

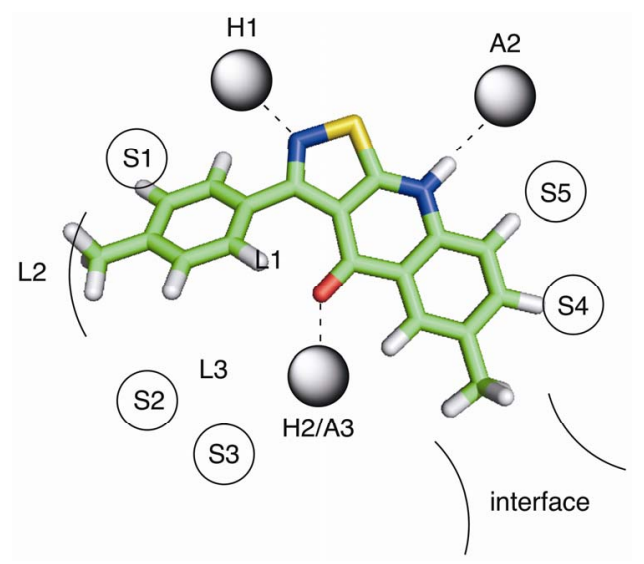

Figure 1. The proposed binding mode of 13 in the pharmacophore model representation. $\mathrm{H} 1$ and $\mathrm{H} 2$ are hydrogen bond donor sites and $\mathrm{A} 2$ and $\mathrm{A} 3$ are hydrogen bond acceptor sites. L1, L2 and L3 represent lipophilic pockets and S1 - S5 denotes regions of steric repulsive ligand-receptor interactions (receptor essential volume). The interface region is a partly lipophilic region and it has been suggested to represent the interface between the $\alpha$ - and $\gamma$-subunits in GABAA receptors.

a hydrogen bond to A2 from $\mathrm{H}-9$, and interact with $\mathrm{H} 2$ / A3 by accepting a hydrogen bond to the carbonyl oxygen. In addition, both types of systems appear to occupy the lipophilic pockets, and not interfere with the steric hindrances.

The 3-arylisothiazolo[5,4- $b]$ quinolin-4(9H)-ones prepared in this investigation, compounds 12 - 16, are potent

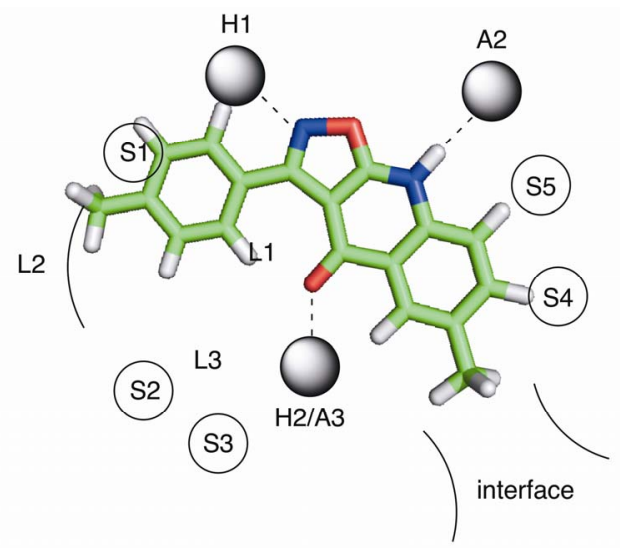

Figure 2. The proposed binding mode of $\mathbf{2 0}$ in the pharmacophore model representation.

inhibitors of $\left[{ }^{3} \mathrm{H}\right]$-Flumazenil binding to the benzodiazepine binding site, with affinities in general in the low $\mathrm{nM}$ range. Obviously, the affinity is not determined by the electron withdrawing/donating properties of the 4'substituent, as $\mathbf{1 4}$ (with a -OMe in position 4') and $\mathbf{1 6}$ (with a $-\mathrm{NO}_{2}$ in position 4') are essentially equipotent. Instead, the intrinsic volume of the 4'-substituent appears to be of greater importance, and the unsubstituted derivative (12) is the least potent. This can be explained by a more efficient interaction with the lipophilic pocket L2 in the pharmacophore model (Figure 1), and is demonstrated by the 13-fold higher affinity of $\mathbf{1 3}$ and $\mathbf{1 4}$ compared to 12. The introduction of methyl-, ethyl- or methoxy-substituents in this region have previously been reported to result in similar increases in the affinity of other benzodiazepine binding site ligands, including flavones $[7,8]$.

Although $\mathbf{1 2}$ and $\mathbf{1 9}$ are approximately equipotent, the 3-arylisoxazolo[5,4- $b$ ]quinolin-4(9H)-ones nevertheless appear to be less potent than the 3-arylisothiazolo [5, 4-b]quinolin-4(9H)-ones in general. This is indicated by the more than 10 times higher affinity of $\mathbf{1 3}$ and $\mathbf{1 6}$ compared to the isoxazoloquinolin-4-one analogues $\mathbf{2 0}$ and 21. The considerably larger size of a sulfur atom compared to an oxygen will affect the size of the fivemembered ring, and thereby the angle between the 3-aryl substituent and the three-ring system. The 3-aryl groups of, for example, compounds $\mathbf{1 3}$ and 20, do consequently not occupy the same space at the binding site. The angle C-1'-C-3-C-3a was calculated (see Experimental) to be 128.2 for $\mathbf{1 3}$ and 131.5 for 20, while the angle C-3-C-3a-C-4 is 131.3 for $\mathbf{1 3}$ and 138.8 for $\mathbf{2 0}$. The distances between the carbonyl oxygen and the closest aromatic proton are consequently different, $1.93 \AA$ in $\mathbf{1 3}$ and $2.04 \AA$ in $\mathbf{2 0}$ (when both structures are forced to be completely planar, vide infra). Although the differences are small, they are visible in Figures $\mathbf{1}$ and $\mathbf{2}$ in which 13 and 20 have been placed in the existing pharma- 
cophore model for ligands binding to the benzodiazepine binding site of $\mathrm{GABA}_{\mathrm{A}}$ receptors. The aryl core as well as the 4' substituent obviously comes in closer contact with S1 and L2 with the isoxazoloquinolin4-one derivatives. This could also be the reason for the equipotency of 19 and 20, while the difference between the isothiazoloquinolin-4-ones $\mathbf{1 2}$ and $\mathbf{1 3}$ is 13-fold. A reasonable explanation for the low affinity of the nitro derivative $\mathbf{2 1}$ would consequently be a sterical repulsive interaction between the nitro group and the receptor essential volume of the binding site. Furthermore, the electron density at the nitrogen in the azole ring as well as the carbonyl oxygen was calculated to be higher for the isothiazoloquinolin-4-ones $(-174$ and $-210 \mathrm{~kJ} / \mathrm{mol}$, respectively, for 13) compared to the isoxazolo-quinolin4-ones (-160 and $-174 \mathrm{~kJ} / \mathrm{mol}$, respectively, for 20 ), enabling the former to interact stronger with $\mathrm{H} 1$ and $\mathrm{H} 2$ in the pharmacophore model. Previous studies have emphasized that ligands with a strong affinity for the benzodiazepine binding site must be able to adopt a planar or close to planar conformation [6]. While the isoxazoloquinolin-4-ones are completely planar in their most stable conformer, the isothiazoloquinolin-4-ones are not. This is caused by the smaller distance between the carbonyl oxygen and aryl group, and in $\mathbf{1 3}$ the dihedral angle for C-2'-C-1'-C-3-C-3a is $39^{\circ}$. However, the energy required to force the phenyl substituent of $\mathbf{1 3}$ into a coplanar conformation was calculated to be only $4.6 \mathrm{~kJ} / \mathrm{mol}$ $(1.1 \mathrm{kcal} / \mathrm{mol})$, and the isothiazoloquinolin-4-ones are consequently able to adopt a planar conformation and thereby comply with the requirement mentioned above.

Subtype testing was performed with compounds $\mathbf{1 3}$ and 19 on recombinant $\alpha_{1} \beta_{3} \gamma_{2}, \alpha_{2} \beta_{3} \gamma_{2}, \alpha_{3} \beta_{3} \gamma_{2}$, and $\alpha_{5} \beta_{3} \gamma_{2}$ receptor subtypes (Table 2). Both compounds display preference for $\alpha_{1} \beta_{3} \gamma_{2}$ over the other receptor subtypes, with $\alpha_{2} / \alpha_{1} K_{\mathrm{i}}$ ratios of 5.8 and $12, \alpha_{3} / \alpha_{1} K_{\mathrm{i}}$ ratios of 2.9 and 5.2 and $\alpha_{5} / \alpha_{1} K_{\mathrm{i}}$ ratios of 2.7 and 9.2 for $\mathbf{1 3}$ and 19, respectively. This has been noted also for other structure types that were developed with this pharmacophore model [9-11], and it seems reasonable to conclude that it is discriminating for the $\alpha_{1} \beta_{3} \gamma_{2}$ subtype.

The pharmacophore model has been used to design several compound classes [9-11] and it seems reasonable to conclude that a substance that fits into the model is likely to display affinity for the BZD site, and furthermore to have a preference for the $\alpha_{1} \beta_{3} \gamma_{2}$ subtype. However, it is a flexible fit and while some $\alpha_{1}$ selective compounds such as -CCT seem to fit well into this model, this is not the case for all $\alpha_{1}$ selective compounds.

\section{CONCLUSION}

The basic structures of 3-arylisothiazolo [5,4-b]quinolin-4(9H)-ones and 3-arylisoxazolo[5,4-b]quinolin-4 (9H)- ones fit the pharmacophore model developed to design novel ligands of the benzodiazepine binding site of $\mathrm{GABA}_{\mathrm{A}}$ receptors, and the 3-arylisothiazoloquinolin-4ones were shown to have high affinity with $K_{\mathrm{i}}$ values close to $1 \mathrm{nM}$. The 3-arylisoxazoloquinolin-4-ones are less potent, and the differences observed both within the two classes of compounds as well as between them are suggested to depend on sterical repulsive interaction with the receptor essential volume of the binding site that is preventing the 3-arylisoxazoloquinolin-4-ones from an efficient interaction with the lipophilic pocket L2 in the pharmacophore model, and/or a higher electron density at the nitrogen in the azole ring $(\mathrm{N}-2)$ as well as the carbonyl oxygen in the isothiazoloquinolin-4-ones compared to the isoxazoloquinolin-4-ones, enabling the former to interact stronger with $\mathrm{H} 1$ and $\mathrm{H} 2$ in the pharmacophore model.

\section{ACKNOWLEDGEMENTS}

Financial support from the Swedish Board for Scientific Research (VR), the Knut and Alice Wallenberg Foundation, the Research School for Pharmaceutical Sciences at Lund University, Carlsberg Foundation, Denmark, and the NeuroScience PharmaBiotec Research Center, Denmark, is gratefully acknowledged.

\section{REFERENCES}

[1] Sieghart, W. (2006) Structure, pharmacology, and function of $\mathrm{GABA}_{\mathrm{A}}$ receptor subtypes. Advances in Pharmacology, 54, 231-263. doi:10.1016/S1054-3589(06)54010-4

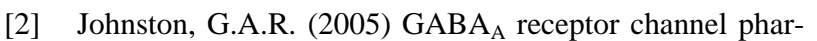
macology. Current Pharmaceutical Design, 11, 18671885. doi:10.2174/1381612054021024

[3] Olsen, R.W. and Sieghart, W. (2009) $\mathrm{GABA}_{\mathrm{A}}$ receptors: Subtypes provide diversity of function and pharmacology. Neuropharmacology, 56, 141-148. doi:10.1016/j.neuropharm.2008.07.045

[4] Rudolph, U., Crestani, F., Benke, D., Brunig, I., Benson, J.A., Fritschy, J.M., Martin, J.R., Bluethmann, H. and Mohler, H. (1999) Benzodiazepine actions mediated by specific gamma-aminobutyric $\operatorname{acid}_{\mathrm{A}}$, receptor subtypes. Nature, 401, 796-800. doi:10.1038/44579

[5] Rudolph, U., Crestani, F. and Möhler, H. (2001) GABA Receptor subtypes: Dissecting their pharmacological functions. Trends in Pharmacological Sciences, 22, 188194. doi:10.1016/S0165-6147(00)01646-1

[6] Zhang, W., Koehler, K.F., Zhang, P. and Cook, J.M. (1995) Development of a comprehensive pharmacophore model for the benzodiazepine receptor. Drug Design and Discovery, 12, 193-248.

[7] Dekermendijan, K., Kahnberg, P., Witt, M., Sterner, O., Nielsen, M. and Liljefors, T. (1999) Structure-activity relationships and molecular modelling analysis of flavonoids binding to the benzodiazepine site of the rat brain 
$\mathrm{GABA}_{\mathrm{A}}$ receptor complex. Journal of Medicinal Chemistry, 42, 4343-4350. doi:10.1021/jm991010h

[8] Kahnberg, P., Lager, E., Rosenberg, C., Schougaard, J., Camet, L., Sterner, O., Østergaard Nielsen, E., Nielsen, M. and Liljefors, T. (2002) Refinement and evaluation of a pharmacophore model for flavone derivatives binding to the benzodiazepine site of the $\mathrm{GABA}_{\mathrm{A}}$ receptor. Journal of Medicinal Chemistry, 45, 4188-4201. doi:10.1021/jm020839k

[9] Lager, E., Andersson, P., Nilsson, J., Pettersson, I., Østergaard Nielsen, E., Nielsen, M., Sterner, O. and Liljefors, T. (2006) 4-Quinolone derivatives: High-affinity ligands at the benzodiazepine site of brain $\mathrm{GABA}_{\mathrm{A}}$ receptors. Synthesis, pharmacology and pharmacophore modelling. Journal of Medicinal Chemistry, 49, 25262533. doi:10.1021/jm058057p

[10] Lager, E., Nilsson, J., Østergaard Nielsen, E., Nielsen, M., Liljefors, T. and Sterner, O. (2008) Affinity of 3-acyl substituted 4-quinolones at the benzodiazepine site of $\mathrm{GABA}_{\mathrm{A}}$ receptors. Bioorganic and Medicinal Chemistry, 16, 6936-6948. doi:10.1016/j.bmc.2008.05.049

[11] Nilsson, J., Østergaard Nielsen, E., Liljefors, T., Nielsen, M. and Sterner, O. (2008) Azaflavones compared to flavones as ligands at the benzodiazepine site of brain $\mathrm{GABA}_{\mathrm{A}}$ receptors. Bioorganic and Medicinal Chemistry Letters, 18, 5713-5716. doi:10.1016/j.bmcl.2008.09.092

[12] Yokoyama, N., Ritter, B. and Neubert, A.D. (1982) 2-Arylpyrazolo[4,3-c]quinolin-3-ones: A novel agonist, a partial agonist and an antagonist of benzodiazepines. Journal of Medicinal Chemistry, 25, 337-339. doi:10.1021/jm00346a002

[13] Shindo, H., Takada, S., Murata, S., Eigyo, M. and Matsushita, A. (1989) Thienylpyrazoloquinolines with high affinity to benzodiazepine receptors: Continuous shift from inverse agonist to agonist properties depending on the size of the alkyl substituent. Journal of Medicinal Chemistry, 32, 1213-1217. doi:10.1021/jm00126a012

[14] Allen, M.S., Hagen, T.J., Trudell, M.L., Codding, P.W., Skolnick, P. and Cook, J.M. (1988) Synthesis of novel 3-substituted-carbolines as benzodiazepine receptor ligands: Probing the benzodiazepine receptor pharmacophore. Journal of Medicinal Chemistry, 31, 1854-1861. doi:10.1021/jm00117a029

[15] Trudell, M.L., Lifer, S.L., Tan, Y.C., Martin, M.J., Deng, L., Skolnick, P. and Cook, J.M. (1990) Synthesis of substituted 7,12-dihydropyrido[3,2-b:5,4-b’]diindoles: Rigid planar benzodiazepine receptor ligands with inverse agonist/antagonist properties. Journal of Medicinal Chemistry, 33, 2412-2420. doi:10.1021/jm00171a015

[16] Albaugh, P., Marshall, L., Gregory, J., White, G., Hutchison, A., Ross, P., Gallagher, D., Tallman, J., Crago, M. and Cassella, J. (2002) Synthesis and biological evaluation of 7,8,9,10tetrahydroimidazo[1,2-c]pyrido [3,4-e]pyrimdin-5(6H)-ones as functionally selective ligands of the benzodiazepine receptor site on the $\mathrm{GABA}_{\mathrm{A}}$ receptor. Journal of Medicinal Chemistry, 45, 5043-5051. doi:10.1021/jm0202019

[17] He, X., Huang, Q., Ma, C., Yu, S., McKernan, R. and Cook, J.M. (2000) Pharmacophore/receptor models for $\mathrm{GABA}_{\mathrm{A}} / \mathrm{BzR} \quad \alpha_{2} \beta_{3} \gamma_{2}, \alpha_{3} \beta_{3} \gamma_{2}$ and $\alpha_{4} \beta_{3} \gamma_{2}$ recombinant subtypes. Including volume analysis and comparison to $\alpha_{1} \beta_{3} \gamma_{2}, \alpha_{5} \beta_{3} \gamma_{2}$ and $\alpha_{6} \beta_{3} \gamma_{2}$ subtypes. Drug Design and Discovery, 17, 131-171.

[18] Kahnberg, P., Howard, M.H., Liljefors, T., Nielsen, M., Østergaard Nielsen, E., Sterner, O. and Pettersson, I. (2004) The use of a pharmacophore model for identification of novel ligands for the benzodiazepine binding site of the $\mathrm{GABA}_{\mathrm{A}}$ receptor. Journal of Molecular Graphics and Modelling, 23, 253-261. doi:10.1016/j.jmgm.2004.06.003

[19] Matsuoka, M., Segawa, J., Makita, Y., Ohmachi, S., Kashima, T., Nakamura, K.-I., Hattori, M., Kitano, M. and Kise, M. (1997) Studies on pyridonecarboxylic acids. V. A practical synthesis of ethyl 6,7-difluoro-1-methyl-4oxo-4H-[1,3]thiazeto[3,2-a]quinoline-3-carboxylate, a key intermediate for the new tricyclic quinolone, prulifloxacin (NM441) and versatile new syntheses of the 2-thioquinoline skeleton. Journal of Heterocyclic Chemistry, 34, 17731779. doi:10.1002/jhet.5570340622

[20] Choi, J.H., Choi, E.B. and Pak, C.S. (2003) Isothiazole ring formation with substituted 2-alkylthio-3-acyl- 4-quinolinone using O-(mesitylenesulfonyl)-hydroxylamine (MSH). Synlett, 2, 166-172.

[21] Chimichi, S., Boccalini, M. and Matteucci, A. (2007) Unambiguous structure elucidation of the reaction products of 3-acyl-4-methoxy-1-methylquinolinones with hydroxylamine via NMR spectroscopy. Tetrahedron, 63, 11656-11660. doi:10.1016/j.tet.2007.08.108

[22] Yoo, K.H., Choi, E.B., Lee, H.K., Yeon, G.H., Yang, H.C. and Pak, C.S. (2006) Beckmann rearrangement using indium(III) chloride: Synthesis of substituted oxazoloquinolines from the corresponding ketoximes of 3-acyl- $1 \mathrm{H}$ quinolin-4-ones. Synthesis, 10, 1599-1612. 